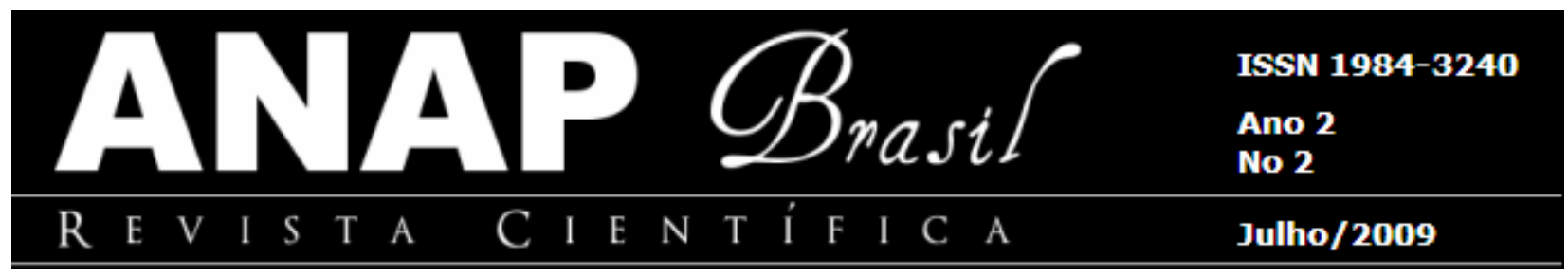

\title{
BIOCOMBUSTÍVEIS: AS CONTRADIÇÕES DO DISCURSO E O DISCURSO DAS CONTRADIÇÕES
}

\author{
Valter Machado da Fonseca ${ }^{1}$
}

Resumo: Este artigo analisa o discurso em defesa dos biocombustíveis, em especial do etanol, veiculado na mídia, no último período. Realizou-se um resgate histórico, por intermédio da pesquisa bibliográfica, das atividades agrícolas do Brasil, investigando as origens de sua vocação agrícola, relacionada historicamente com as monoculturas de exportação. Verifica-se que este discurso é artificial, construído nos gabinetes e não nos centros de pesquisas científicos idôneos. Verifica-se ainda que sua defesa se edifica sobre argumentos construídos com base em artifícios pseudoecológicos, desconsiderando-se os impactos sócio-ambientais existentes em cada etapa de sua cadeia produtiva. Por fim, ele aponta no sentido de se instigar as investigações científicas, no sentido do aproveitamento da energia solar, como uma forma de energia verdadeiramente limpa. Dominar os processos de utilização desta forma de energia constitui-se no grande desafio para a ciência, neste limiar do século XXI.

Palavras-Chave: Energia. Biocombustíveis. Impactos sócio-ambientais

\section{INTRODUÇÃo}

\footnotetext{
${ }^{1}$ Técnico em Mineração pela Escola Técnica Federal de Ouro Preto (ETFOP) - MG, Licenciado em Geografia pela Universidade Federal de Uberlândia (UFU) - MG, Mestre em Educação pela Faculdade de Educação da Universidade Federal de Uberlândia (FACED/UFU). Professor convidado do curso de Geografia e Educação Ambiental da Universidade de Uberaba (UNIUBE) e pesquisador das temáticas: "Alterações Climáticas" e "Impactos das monoculturas sobre os biomas brasileiros".
} 


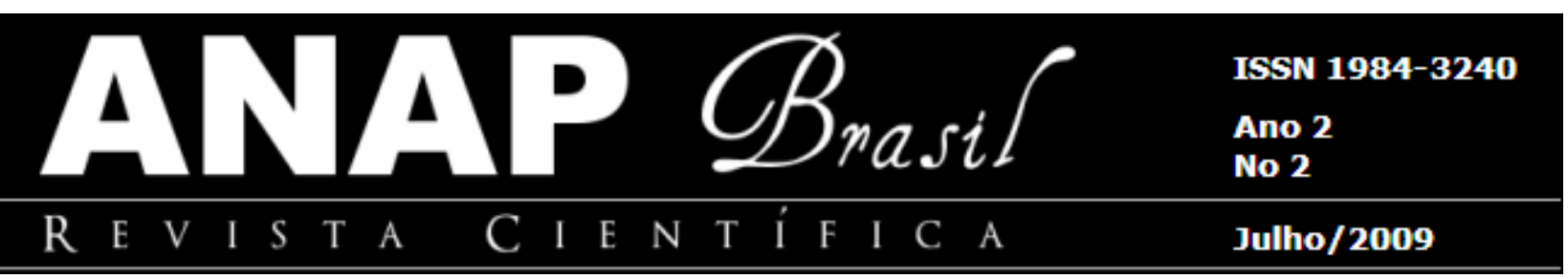

Este trabalho nasce não apenas da vontade de escrever sobre a temática, mas, sobretudo da necessidade de uma resposta urgente ao que vem acontecendo (e ao que está por acontecer) em relação à produção agrícola no Brasil. O país sempre se destacou pela especulação no mercado internacional de produtos agrícolas, visando em primeira instância, atender às demandas das grandes potências capitalistas e, em última instância, às necessidades da maioria de sua população.

Desde a colonização, o país prima pelas monoculturas de exportação, mas foi a partir das últimas décadas, em particular, que o país se definiu de forma intensa e de uma vez por todas, em favor desse tipo de atividade. Toda a política agrícola brasileira vem priorizando o desenvolvimento de novas tecnologias e novas técnicas de plantio, voltadas para essas monoculturas. No mesmo sentido, o Estado brasileiro vem aumentando substancialmente, os subsídios voltados para essas atividades, ao mesmo tempo em que oferece incentivos e promove a queda das taxas de juros para o setor agrícola agro-exportador, beneficiando os grandes grupos e conglomerados agroindustriais multi/transnacionais e reduzindo as possibilidades dos pequenos produtores rurais que vivem e/ou viviam da agricultura de subsistência. Isto tudo, sem mencionar a pouca visibilidade das políticas públicas voltadas para as comunidades indígenas, quilombolas e extrativistas.

Os anos 1980 e 1990 foram marcados, fundamentalmente, pelo auge da monocultura da soja. Pode-se dizer que esta atividade, extremamente lucrativa para poucos, levou grande número de pequenos produtores à ruína abrindo definitivamente, o flanco para a exploração irracional e definitiva dos biomas brasileiros, principalmente o Cerrado. Hoje já se observa o início da decadência da monocultura da soja e a quase extinção do bioma Cerrado.

O novo milênio inaugura a estratégia da volta da monocultura da cana-deaçúcar, como "tapa-buraco" para sanar a possível falta de energia ocasionada pelo prenúncio do fim do "Ciclo do Petróleo".

A estratégia da volta da monocultura da cana-de-açúcar não é algo inusitado, muito pelo contrário, trata-se de uma política milimetricamente planejada e que tudo 


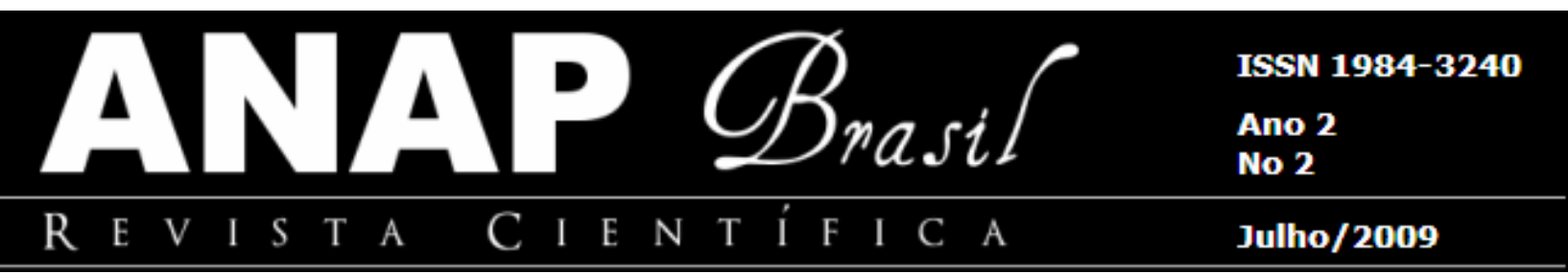

leva a crer, sob a orientação da Casa Branca. Ela já vem sendo estudada e planejada há pelo menos três décadas sob a regência dos diversos governos brasileiros em cooperação com os EUA. Não foi à toa a recente visita de George W. Bush ao Brasil e aos principais países da América Latina. Na verdade, a Área de Livre Comércio das Américas (ALCA), vem sendo implantada na prática, sem nenhum acordo assinado no papel, mas por intermédio de ações "multilaterais" (na verdade unilaterais, pois, visa atender aos interesses norte-americanos), das quais o Brasil é o grande pivô.

O retorno da monocultura da cana-de-açúcar, agora acompanhada de tecnologia de última geração, coloca o etanol como o grande ator no cenário políticoeconômico que se desenha, ou seja, propiciar o respiro necessário aos EUA, garantindo a eles o tempo suficiente para reestruturar sua matriz energética. $A$ derrocada dos EUA no Iraque acelerou, de forma substancial, a Geopolítica de produção do etanol.

É exatamente dentro deste contexto sócio-político e econômico, que este artigo discute a problemática das monoculturas no Brasil, em especial a cana-de-açúcar. Este trabalho tem o propósito de alertar as comunidades acadêmico/científicas, a sociedade civil organizada, a população em geral e, em especial, os pequenos produtores rurais que vêem na monocultura da cana-de-açúcar, a oportunidade de alta lucratividade em curto espaço de tempo e/ou uma panacéia ${ }^{2}$ para sanar todos seus problemas financeiros. É ainda dentro deste contexto que este trabalho visa decifrar uma parcela da degradação sócio-ambiental escondida por detrás dos "nós" da cana, nos biomas brasileiros.

\section{A VOCAÇÃO AGRÍCOLA BRASILEIRA E A PRÁTICA DAS MONOCULTURAS}

\footnotetext{
${ }^{2}$ Espécie de garrafada vendida pelos camelôs, que serve para curar todo tipo de doença. Remédio para todos os males.
} 


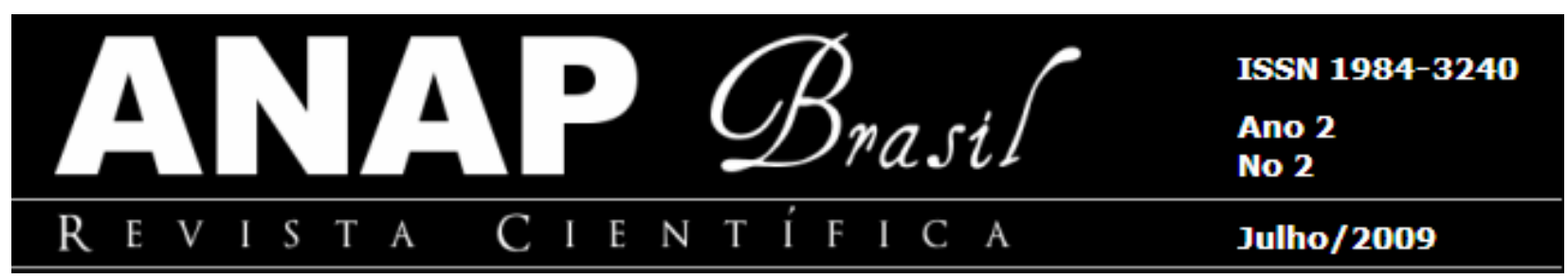

A vocação agrícola do Brasil surgiu da imposição da prática das monoculturas desde o início do processo de colonização do país. Este tipo de atividade abriu o flanco para a degradação sócio-ambiental do território brasileiro, exterminando etnias, culturas, além dos recursos naturais, principalmente a degradação dos solos e contaminação dos corpos d'água.

Para iniciar este tópico, nada mais oportuno que a primeira impressão de Pero Vaz de Caminha sobre a descoberta das "novas terras", registrada em carta, datada do dia $1^{\circ}$ de maio de 1500 , da ilha de Vera Cruz e endereçada ao rei de Portugal:

\begin{abstract}
Esta terra, senhor, parece-me que, da ponta que mais contra o sul vimos, até a outra ponta que contra o norte vem, de nós deste porto houvemos vista, será tamanha que haverá nela bem vinte ou vinte e cinco léguas de costa. Traz ao longo do mar, em algumas partes, grandes barreiras, umas vermelhas, e outras brancas; e a terra de cima toda chã e muito cheia de grandes arvoredos. De ponta a ponta é toda praia...muito chã e muito formosa. Pelo sertão nos pareceu, vista do mar, muito grande; porque a estender os olhos não podíamos ver senão terra e arvoredos - terra que nos parecia muito extensa. Até agora não pudemos saber se há ouro ou prata nela, ou outra coisa de metal, ou ferro; nem Iha vimos. Contudo, a terra em si é de muitos bons ares frescos e temperados como os Entre-Douro-e-Minho, porque neste tempo d'agora assim os achávamos como os de lá. Águas são muitas; infinitas. Em tal maneira é graciosa que, querendo-a aproveitar, darse-á nela tudo, por causa das águas que tem.
\end{abstract}

Na verdade, a carta de Pero Vaz traz em suas entrelinhas toda a "lógica" do discurso hegemônico de estratégia da implantação do modo de produção capitalista, que estava em gestação no período das grandes navegações. Os grandes impérios da época viam na conquista de novas colônias a oportunidade de enriquecimento a qualquer custo, além da imposição da cultura branca e machista européia. A referência à quantidade de água existente na ilha de Vera Cruz deixa claro que, na pior das hipóteses, ou seja, na inexistência de metais preciosos, a fertilidade da terra poderia ser explorada para suprir as necessidades de gêneros alimentícios da 


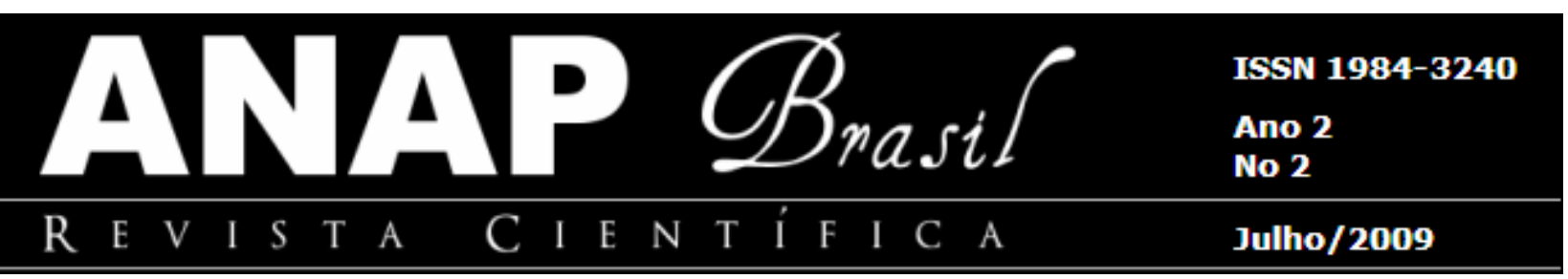

Europa, principalmente os produtos mais rentáveis e de maior demanda no mercado do ocidente.

2.1 DE FOICES, FACÕES E MACHADOS: O INÍCIO DA PILHAGEM DA BIODIVERSIDADE BRASILEIRA.

A carta de Caminha teve efeito quase que imediato, rapidamente despertou a cobiça da coroa portuguesa. A densa floresta que se estendia ao longo do litoral brasileiro foi o primeiro objeto de cobiça de Portugal, por dois motivos básicos: o primeiro foi sua localização geográfica, situada numa área de fácil acesso, próxima ao mar e ao porto; o segundo foram os preços alcançados na Europa, principalmente de espécies vegetais, das quais se podiam extrair fibras para os teares europeus. Em seguida, descobriu-se a propriedade de uma espécie de muita abundância, na "nova terra" naquele período, o pau-brasil, cuja principal propriedade era seu pigmento avermelhado, muito valorizado para a fabricação de tintas e corantes, utilizados para tingir os tecidos fabricados nos teares do ocidente.

Iniciava-se naquele instante, a pilhagem do potencial florístico brasileiro com a exploração dos nossos recursos vegetais, principalmente do pau-brasil. Além das espécies vegetais, também eram mandadas para a Europa, aves, como a Arara e o Papagaio. A riqueza dos recursos naturais do país vem despertando a cobiça dos povos de todas as partes do mundo, o que vem impulsionando o tráfico do patrimônio florístico e faunístico do Brasil, a biopirataria. O termo biopirataria é aparentemente novo, apesar do tráfico do patrimônio florístico brasileiro, constituir-se numa prática que remonta à época do descobrimento do Brasil, há 500 anos atrás.

A exploração desordenada da madeira brasileira inaugurou um período de "rapinagem" dos recursos florísticos de um dos mais ricos biomas do país: a Mata Atlântica. Hoje este bioma está, praticamente, extinto restando apenas manchas da vegetação original (cerca de 10\%). Pode-se afirmar que a biopirataria, além de realizar a pilhagem de nossa biodiversidade, também se apropria da cultura e dos 


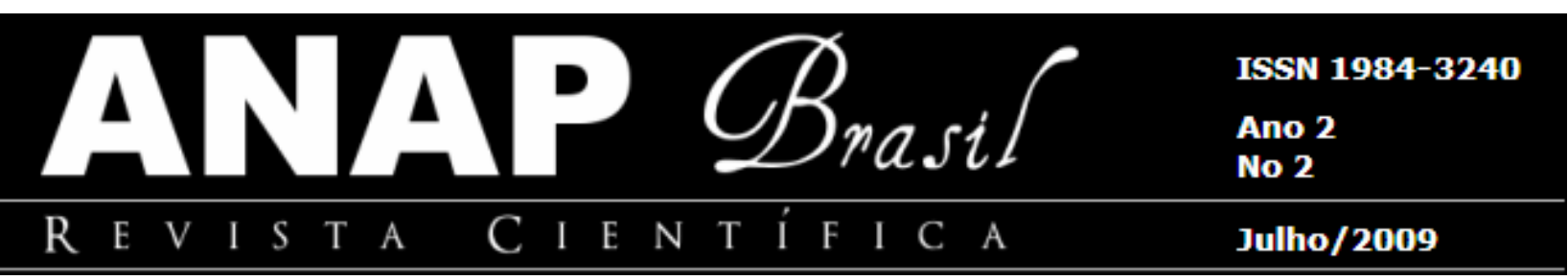

saberes das comunidades que habitam os biomas brasileiros desde antes do "descobrimento" do país.

A carta de Caminha dá indícios de um clima equilibrado e ameno no Nordeste do Brasil, quando se analisa um pequeno recorte textual: "a terra em si é de muitos bons ares frescos e temperados como os Entre-Douro-e-Minho, porque neste tempo d'agora assim os achávamos como os de lá". Veja que ele chega a fazer a comparação com uma região de Portugal, de clima ameno e fresco. Esta narrativa é um indício de que o clima na região Nordeste não sofria o desequilíbrio, pelo qual passa nos dias atuais, o que significa que a existência da Mata Atlântica era fundamental para o equilíbrio climático da região, mantendo, inclusive a regularidade das chuvas e a fertilidade dos solos. Isto demonstra a relevância do trabalho de Josué de Castro, que relacionava a vegetação densa da floresta às condições edáficas e à fertilidade dos solos do Nordeste. Castro disserta sobre as proporções do desmatamento:

A destruição da floresta alcançou tal intensidade e se processou em tal extensão, que nesta região chamada Mata do Nordeste, por seu revestimento de árvores quase compacto, restam, hoje apenas pequenos retalhos esfarrapados deste primitivo manto florestal. No Estado de Pernambuco, onde a devastação alcançou o máximo, a área atualmente recoberta pelas florestas não atinge, conforme avaliação de um estudioso do assunto, o agrônomo Vasconcelos Sobrinho a $10 \%$ da superfície total do Estado. Resta apenas um resíduo da mata primitiva já sem nenhuma expressão econômica. (CASTRO, 1963, p. 144)

A citação de Castro (1963) demonstra quão grave foi o desmatamento no Nordeste brasileiro pela cobiça da coroa portuguesa. O autor continua sua argumentação:

Mas não foi só atuando sobre as condições edáficas da região, sobre a riqueza e qualidade do solo, que o desflorestamento se constituiu em fator de degradação do Nordeste, mas também fazendo minguar os recursos da fauna regional, cuja vida estava intimamente ligada à própria vida da floresta. Recursos representados pelas caças que aí se encontravam e que eram importantes fontes de abastecimento do índio e mesmo do colono, nos seus 


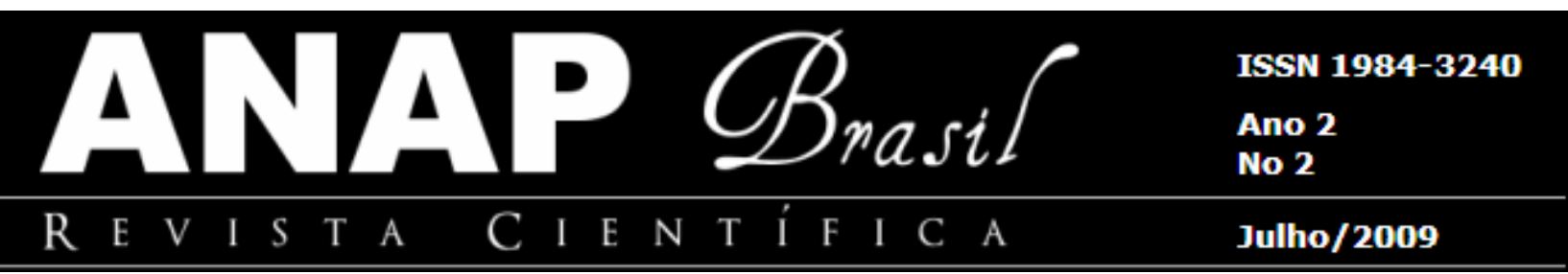

primeiros tempos de vida na nova terra. Pero de Magalhães Gandavo afirmou que "uma das coisas que sustenta e abasta muito os moradores desta terra do Brasil é a muita caça que há nestes matos, de muitos gêneros e de diversas maneiras". E falava nos veados e porcos selvagens, coelhos e antas, pacas e tatus. Estes e outros elementos da fauna nordestina foram sendo pouco a pouco dizimados, afugentados pelas coivaras, se escondendo nas nesgas de mata cada vez mais ralas, mais limitadas, até quase se extinguirem de vez. (CASTRO, 1963, p.149-150)

Pelos depoimentos acima é possível se ter uma idéia da voracidade do ataque sobre os recursos naturais da colônia portuguesa, ou seja, sobre os recursos naturais brasileiros. Neste sentido, cai por terra a argumentação de muitos estudiosos que tentam isolar o problema do desequilíbrio climático e da aridez do solo nordestino, da ação desordenada do homem sobre os recursos da natureza.

O problema da retirada da Mata Atlântica ainda iria ser agravado com a introdução da monocultura da cana-de-açúcar na região, o que será tratado mais adiante. Assim, a exploração do Pau-Brasil abriu caminho para o início da degradação ambiental dos biomas brasileiros, além do extermínio de comunidades indígenas inteiras, e da imposição do sistema de escravização dos negros vindos do continente africano.

A "lógica" da exploração dos recursos naturais do Brasil, no século XVI, foi de encontro à estratégia de exploração das diversas colônias espalhadas por todo o mundo, em especial as das Américas do Sul e Central e do continente africano. Em primeiro lugar, o potencial de uma colônia conquistada se media pela quantidade de metais preciosos nela existente, em segundo lugar a predação se dava por intermédio das monoculturas para atender o mercado europeu, principalmente aquelas de maior valor comercial.

Neste sentido, as grandes descobertas, na verdade, prepararam a base material para a Revolução Industrial que iria ocorrer posteriormente na Inglaterra e consistiria no suporte material para a inauguração do modelo capitalista de produção. Pode-se afirmar que o Brasil, desde o descobrimento serve de âncora para sustentar as grandes potências capitalistas mundiais. Sempre se manteve colado aos discursos 


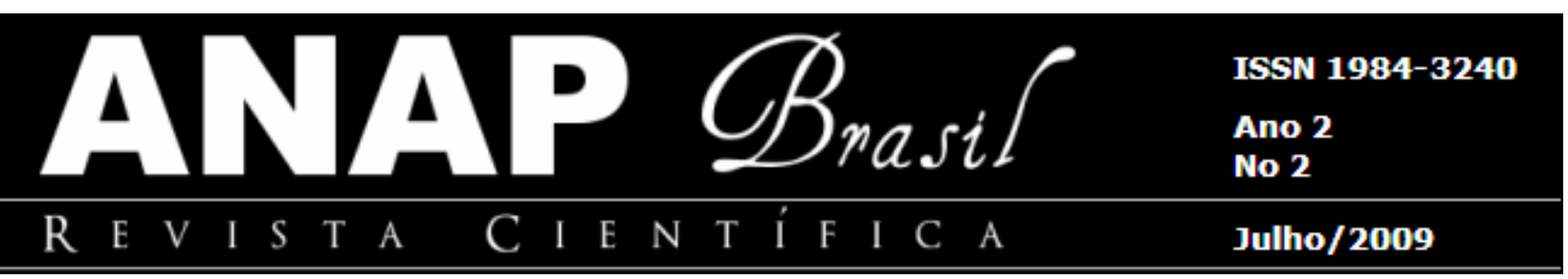

falaciosos da negociação (entrega) de seus preciosos recursos naturais, em troca de um pseudo-desenvolvimento também embasado no arcabouço discursivo ilusório, justificando a prática das monoculturas, embasada na especulação de produtos agrícolas que atendessem às demandas do mercado consumidor europeu e, posteriormente norte-americano.

A devastação quase que total da Mata Atlântica significou uma perda incalculável não somente no que concerne à destruição da biodiversidade, como também contribuiu para os prejuízos referentes à erosão e perda da fertilidade dos solos, ao desequilíbrio climático, com alterações substanciais no regime de precipitações pluviométricas, além de acelerar, sobremaneira, os processos de poluição das águas superficiais e subterrâneas. No que se refere à biodiversidade, foi extinta uma enorme quantidade de espécies tanto vegetais como animais, endêmicas daquela faixa costeira do litoral brasileiro.

A monocultura da cana-de-açúcar inaugurou o ciclo de degradações sócioambientais no país, além de justificar a prática do escravagismo (com base na exploração da mão-de-obra africana) e de extermínio de milhares de comunidades indígenas.

\section{O ATUAL MODELO ECONÔMICO DE PRODUÇÃO E A CRISE ENERGÉTICA MUNDIAL}

A Revolução Industrial inaugurou um novo ciclo de degradações ambientais no planeta. Toda inovação tecnológica necessita em primeiro lugar de energia, para que possa ser colocada em prática. Assim, também para fazer funcionar as máquinas, engenhos e locomotivas a vapor, foi necessário combustível para a produção de energia. Neste sentido, o carvão vegetal foi o primeiro combustível utilizado para 


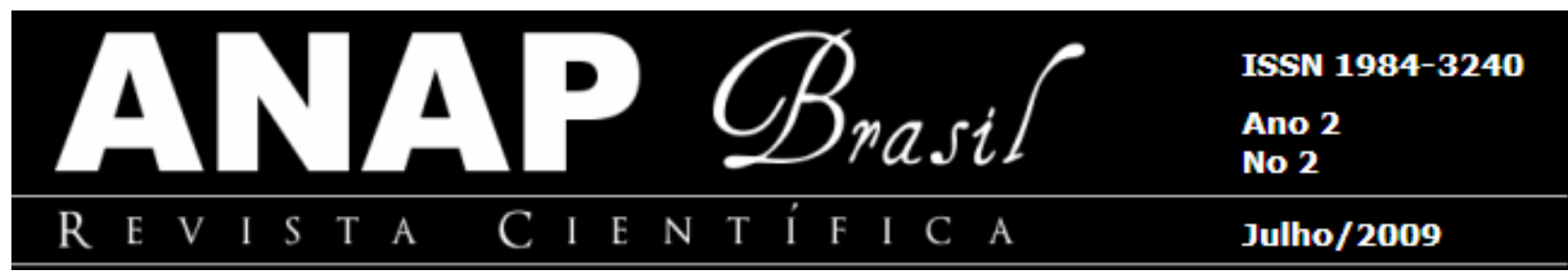

fazer funcionar os engenhos e locomotivas, na primeira etapa da Revolução Industrial, acelerando o processo de degradação ambiental do planeta.

Durante toda sua existência na Terra, o homem vem numa busca constante por novas formas de energia. A cada nova invenção, nova inovação no processo produtivo, mais quantidade de energia é necessária. A invenção do motor a explosão (Segunda Revolução Tecnológica) iniciou a exploração dos combustíveis fósseis como nova forma de energia, que revolucionou todo o processo produtivo da sociedade capitalista. Hoje, já se anuncia o prenúncio do fim do ciclo do petróleo e o mundo já vislumbra, para um futuro que se confunde com o presente, uma nova crise energética. Podemos concluir que a energia não somente é a grande responsável pela continuidade da vida na Terra, como também para garantir as atividades humanas no planeta. Estas considerações são importantes, pois, o consumo de energia está diretamente ligado à degradação ambiental do planeta.

Dias (2002, p. 57) ilustra o crescimento da degradação ambiental no planeta, considerando-se a interferência humana nos ecossistemas:

\begin{abstract}
Segundo o IGBP (International Geosphere-Biosphere Programme, 1990), durante a geração passada, o ambiente da Terra mudou mais rapidamente do que qualquer outro tempo comparável na história. Embora os fenômenos naturais tenham um papel importante nessas mudanças, a fonte primária dessa dinâmica tem sido precipitada pelas interações do ser humano com a biosfera. Tais influências, produzidas de modo inadvertido ou propositado, criaram e criarão mudanças globais dramáticas que alterarão a existência humana por muito tempo. Tais mudanças globais são resultados das relações políticas, sociais, econômicas e religiosas da humanidade com a Terra. Agricultura, silvicultura ${ }^{3}$, produção e padrões de consumo de energia e materiais, aumento da população, urbanização e outras atividades humanas alteraram os ecossistemas aquáticos, terrestres e a atmosfera da Terra.
\end{abstract}

\footnotetext{
${ }^{3}$ Grifo meu. O termo refere-se ao plantio de florestas com espécies vegetais exóticas (principalmente o eucalipto e o pinus). Muitos confundem silvicultura com reflorestamento. Silvicultura significa o replantio de áreas com espécies vegetais exóticas e/ou nativas visando à exploração comercial. Já o reflorestamento é o replantio de áreas com espécies vegetais características (originais) da própria região visando, geralmente, a recuperação da vegetação de áreas degradadas.
} 


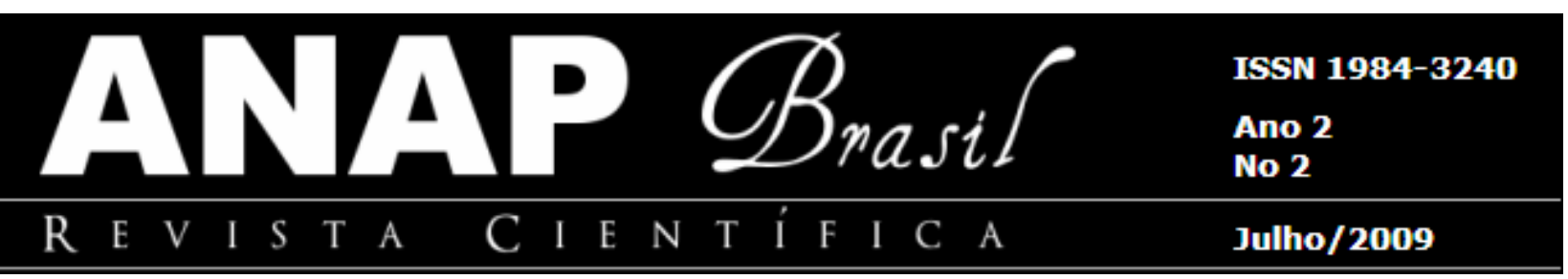

A formulação de Dias descreve as alterações ocasionadas nos ecossistemas terrestres, o que provoca 0 intenso desequilíbrio sócio-ambiental nesses ecossistemas. No mesmo sentido, este desequilíbrio têm se tornado mais intenso e mais grave, na medida em que ocorre o desenvolvimento das técnicas, objetivando o aprimoramento da cadeia produtiva e da mais-valia capitalista, o que está diretamente relacionado com a expansão e reprodução do capital. $E$ todo este processo de aprimoramento do atual modelo econômico está diretamente relacionado com a demanda por maiores quantidades e/ou novas formas de energia.

No mesmo sentido, o aprimoramento e o desenvolvimento de novas tecnologias possui estreita relação com o poder político e econômico e, até mesmo com a segurança do planeta, pois a produção do conhecimento traz em suas entrelinhas, ideologias e intencionalidades. Pode-se dizer que as técnicas estão encharcadas de ideologias, de poder, conforme afiança Gonçalves (2006, p. 79):

\begin{abstract}
Não existe técnica sem uso prático e essa distinção é, rigorosamente, absurda. Afinal, e eis uma outra característica importante do fenômeno técnico, a técnica traz em seu uso a intenção em estado prático: por meio da técnica, meios e fins se tornam praticamente concretos. Assim, é sempre bom insistir, a técnica não é paralela nem tampouco exógena às relações sociais e de poder. Deste modo, uma crítica à técnica, mesmo que a uma determinada técnica específica é, sempre, uma crítica às intenções nela implicadas e, assim, se introduz uma tensão, uma dubiedade, lá mesmo onde se acreditava haver uma ação simplesmente racional que se acreditava unívoca e, por isso, inquestionável. Entretanto, toda técnica, sendo meio, está a serviço de um $\mathrm{fim}^{4}$, seja um arco e flecha, seja uma enxada, seja um míssil.
\end{abstract}

Assim, a busca de novas formas de energia está conciliada com as disputas territoriais, pelas disputas em torno das reservas naturais de energia (vide invasão do Iraque pelos EUA), em torno de técnicas de produção de energia (como a tecnologia nuclear).

A humanidade assiste, neste início de século, ao fim de um recurso natural não renovável: o petróleo. A geopolítica do petróleo, neste limiar de século, tem servido

\footnotetext{
${ }^{4}$ Grifos do original.
} 


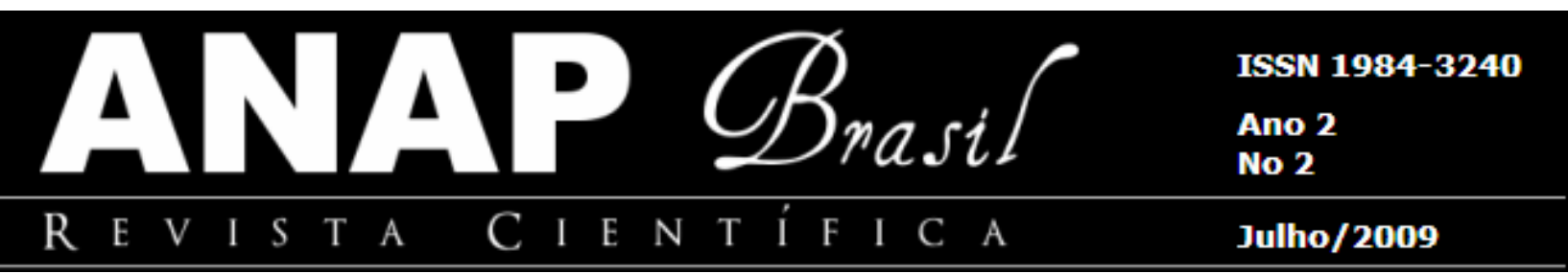

de subterfúgio para ameaçar a autonomia e a autodeterminação dos povos, justificativas, escondidas atrás de discursos "anti-terror" e "anti-nucleares", para invasão de territórios, principalmente daqueles onde se encontram as maiores jazidas deste recurso natural. Em nome de subterfúgios espúrios, justificam-se guerras e carnificinas. Por outro lado, a utilização dos combustíveis fósseis tem sido a maior responsável pela poluição e degradação do planeta, desde que eles foram descobertos como forma de energia.

A indústria automobilística é hoje, sem sombra de dúvida, a principal responsável pela emissão de gases tóxicos para a atmosfera, principalmente o dióxido de carbono $\left(\mathrm{CO}_{2}\right)$. Os subprodutos do petróleo fabricados nos pólos petroquímicos, a exemplo dos plásticos, são os grandes vilões da superprodução de lixo doméstico e industrial, transformando o planeta em um grande depósito de resíduos. Neste último período, em particular, assiste-se à progressão, sem precedentes, do aumento do nível dos oceanos e da temperatura da Terra (aquecimento global), o que incide, diretamente, sobre as drásticas alterações climáticas (derivadas do aumento dos gases-estufa) que sevem de "sinal de alerta" acerca do futuro incerto de todas as espécies de seres vivos, dentre elas o Homo Sapiens. Agora, o ciclo do petróleo está em sua fase derradeira.

A utilização do petróleo como fonte energética tem por embasamento o seu alto grau de combustão. Trata-se da utilização da energia concentrada na molécula de carbono (C), que foi acumulada há milhões de anos atrás, fotossintetizada, fossilizada e mineralizada, conservando, dessa maneira, um alto poder de combustão, diferentemente da molécula de carbono existente nos biocombustíveis, em especial no etanol. A energia produzida pelo petróleo passou pela ação lenta e gradual dos elementos da natureza sobre a molécula de carbono, durante milhões e até bilhões de anos (em tempo geológico).

O homem, no afã de resolver seu problema energético, apropriou-se deste recurso natural - não renovável, diga-se de passagem, pois envolve períodos e eras geológicas (milhões e bilhões de anos), para sua produção. Neste sentido, aquilo que 


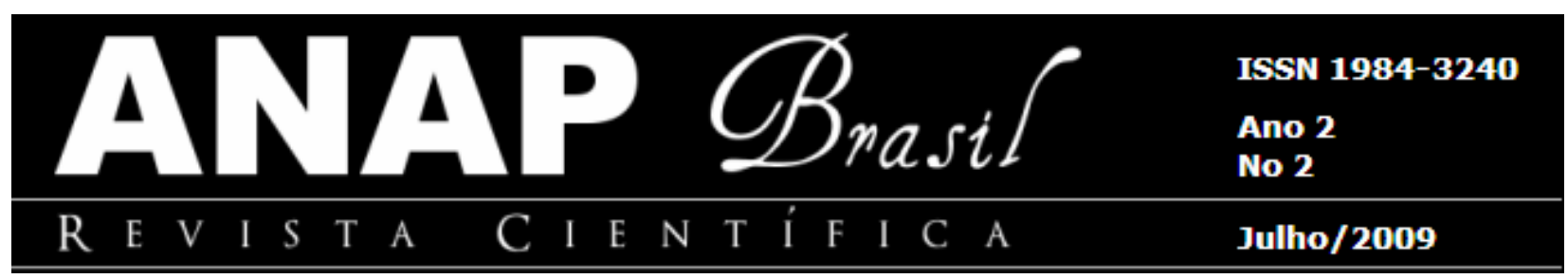

a natureza se encarregou de produzir e soterrar em grandes profundidades, o homem conseguiu extrair e recolocar na atmosfera terrestre. Gonçalves (2006, p. 328) ilustra esta situação:

[...] com o uso generalizado dos combustíveis fósseis se está devolvendo à atmosfera substâncias químicas que o próprio petróleo e carvão, enquanto fósseis, abrigam em seus corpos. Assim, o carbono, que com a ajuda da fotossíntese havia sido feito corpo vivo, depositado a grandes profundidades, submetidos a enormes pressões e temperaturas durante um tempo que se conta em milhões de anos (em tempo geológico), tornou-se carvão e petróleo que, hoje, explodimos (motor a explosão) e, assim, devolvemos à atmosfera aquilo que dela havia sido retirado. Saliente-se que a retirada dessas substâncias químicas que ficaram mineralizadas no petróleo e no carvão, sobretudo o gás carbônico absorvido, diminuíram o efeito estufa, tornando possíveis as temperaturas aos níveis atuais e, desse modo, a evolução da vida tal qual a conhecemos. A devolução dessas substâncias à atmosfera faz aumentar novamente o efeito estufa alterando as condições da vida. Eis a situação atual.

Conforme o texto de Gonçalves é possível imaginar o impacto ocorrido sobre a dinâmica da natureza e sobre o equilíbrio do planeta, pelo uso despreocupado dos combustíveis fósseis. O homem contrariou de forma irresponsável, a dinâmica natural e o equilíbrio ambiental do planeta Terra. Isto, não significa que devemos negar a evolução e o desenvolvimento da ciência e das técnicas, mas chama-nos à atenção para o planejamento, gestão e manejo corretos dos recursos naturais.

Apesar das descobertas de novas jazidas de petróleo, carvão mineral e gás natural, é inegável o esgotamento destes recursos, a curto e médio prazo. A iminência de uma crise energética global já se faz sentir e, a matriz energética da cadeia produtiva capitalista foi construída majoritariamente em função destes combustíveis. E, esta constatação faz surgir especulações sobre a descoberta de novas formas de energia. Traz à tona discussões já há tempos superadas pela história. É, exatamente, neste ponto que ressurge o discurso inconsistente em prol dos biocombustíveis, em especial o etanol e o retorno da monocultura canavieira com todas suas nuances. Assunto que será desenvolvido a partir do próximo tópico. 


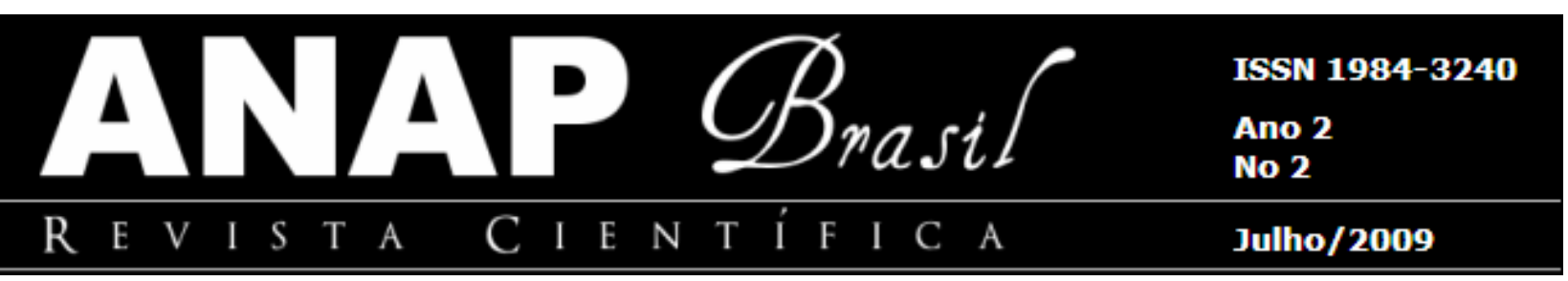

\section{BIOCOMBUSTÍVEIS: UM DISCURSO INCONSISTENTE}

O discurso oficial do governo brasileiro tem alardeado pelos quatro cantos do Brasil e até para longínquas regiões do planeta, argumentos que colocam os biocombustíveis como a grande saída para superar a crise energética mundial. Porém, tais discursos estão sobre pilares artificiais, fictícios, construídos por intermédio de argumentação não científica, com forte apelo propagandístico e sensacionalista.

Tais discursos, em última instância visam construir o marketing político do governo brasileiro, ao mesmo tempo em que abrem espaços e oportunidades para os grandes grupos ligados à tradicional oligarquia rural nordestina, que migram suas atividades do nordeste, principalmente para a região Sudeste do país. Eles mantêm, até os dias atuais, a mesma política dos tempos coloniais. Além destes grupos, também se beneficiam deste marketing, os banqueiros e as grandes montadoras de automóveis, que têm aumentado, exponencialmente, as vendas de veículos automotores. É importante ressaltar que esses discursos encontram respaldo nos grandes veículos de comunicação de massas. São discursos construídos a partir de lemas tais como, "ecologicamente correto", "combate à poluição atmosférica", defesa [intransigente] da "energia limpa" e principalmente "salários e condições dignas para os trabalhadores rurais.

lludem-se, lamentavelmente, aqueles que acreditam que o discurso em defesa dos biocombustíveis, em especial do etanol, tem como eixo central a suposta preocupação com o ambiente ecologicamente equilibrado. Na verdade, apesar desse tipo de energia não conseguir superar a incontestável crise do petróleo e seus derivados, ela permite prolongar a vida útil das principais reservas mundiais de combustíveis fósseis. Isto permite o respiro necessário aos principais conglomerados multi/transnacionais discutirem a questão e acharem uma saída para substituir a 


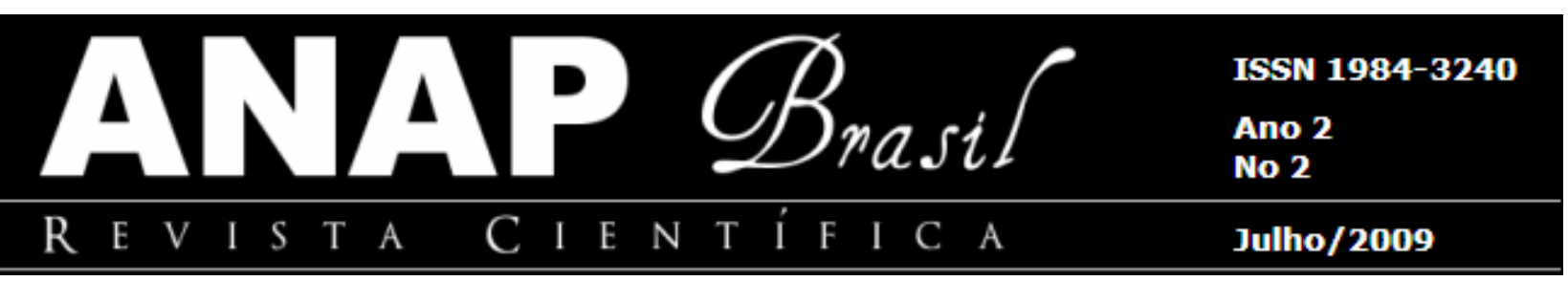

matriz energética petrolífera, sem abrir mão de seus lucros excepcionais. Prova disso é a preocupação com investimentos em biocombustíveis por parte de diversos países do Oriente Médio conforme testemunha Bourne Jr. (2007, p. 76):

\begin{abstract}
O fascínio pelos biocombustíveis vegetais parece ter chegado aos desertos ricos em petróleo do Oriente Médio. Os Emirados Árabes Unidos destinaram 250 milhões de dólares a um programa de pesquisa de energia renovável que inclui os biocombustíveis - talvez um sinal de que até os xeques começam a se dar conta de que a era do petróleo não vai durar para sempre.
\end{abstract}

Embora a quantia citada acima (U\$250.000.000) seja quase que irrisória, considerando-se a lucratividade das nações da Organização dos Países Produtores de Petróleo (OPEP), o investimento é um indício de que as reservas do produto estão se exaurindo e que esses países estão procurando uma saída a médio prazo, para sanar a crise energética sem abrir mão de seus lucros exorbitantes. Na verdade, nas entrelinhas dos discursos em defesa do etanol, existe um forte viés ideológico que visa mascarar, camuflar, diluir os graves problemas sócio-ambientais crônicos que marcam a vida das populações dos países denominados de "emergentes" ou "em desenvolvimento".

É preciso enfatizar que o Estado brasileiro, por intermédio do discurso próetanol tem propagado uma falsa concepção de progresso e de desenvolvimento. Neste ponto, a mídia cumpre seu papel de caixa de ressonância deste discurso e faz com que ele se propague em todas as camadas da sociedade. A argumentação parte, exatamente, dos problemas mais sentidos pela população, ou seja, o desemprego e os baixos salários, principalmente da parcela mais carente. Falando em nome da criação de mais empregos, melhores salários e melhores condições de vida, o discurso pró-biocombustíveis ganha a confiança das massas.

É interessante verificar, que até há pouco tempo, a grande mídia vinha fazendo algumas reportagens que mostravam os desmandos e o sofrimento de homens, mulheres e crianças que trabalhavam no corte da cana-de-açúcar. Hoje, o discurso está de tal forma afinado entre os setores interessados, que dificilmente se vê as 


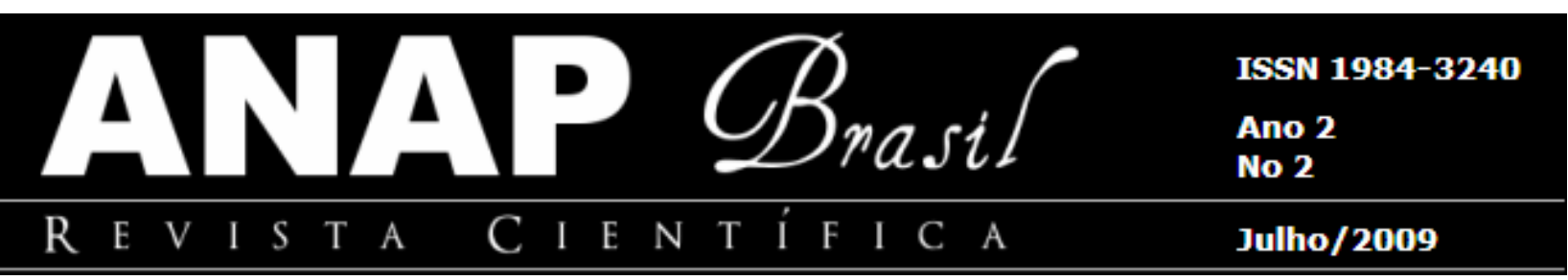

reportagens que tomou conta da mídia até bem pouco tempo. O controle do aparato discursivo sobre as massas se dá de forma camuflada, sutil. Horkheimer e Adorno fazem uma importante formulação a respeito do domínio do discurso demagogo sobre a população:

\begin{abstract}
Hoje em dia, muito se discute, e não sem fundamentos, sobre a técnica de domínio das massas. Mas é preciso ter cuidado com a idéia de que os demagogos que as usam surgem à margem da sociedade e que, depois, por acaso ou em virtude do emprego abusivo de instrumentos técnicos de persuasão, obtêm um poder sobre os outros homens, os mais justos e pacíficos, passando a agir como assaltantes da diligência do progresso. Na realidade, esses demagogos já não correspondem à figura isolada do "tocador de tambor", em que eles querem se arvorar, nem são simples loucos ou psicopatas que conseguem penetrar no recinto da sociedade normal; eles são, outrossim, expoentes de forças e interesses sociais mais poderosos, que conseguem predominar contra as massas e com a ajuda destas. O triunfo ou o fracasso do demagogo não depende apenas da técnica de domínio sobre as massas, mas também da possibilidade e capacidade para integrar a massa aos objetivos do mais forte. (HORKHEIMER e ADORNO, 1986, p.86).
\end{abstract}

E quem é o mais forte no caso dos biocombustíveis? Com toda certeza é o Estado brasileiro [representando os grandes grupos multi/transnacionais do setor], os usineiros, os banqueiros e as montadoras de automóveis. Para onde vão as divisas geradas pela cadeia produtiva dos biocombustíveis? Estas são algumas das perguntas que não querem calar.

O conhecimento que se tem produzido acerca das vantagens e da eficiência dos biocombustíveis é artificial, forjado dentro dos gabinetes e não nos centros de pesquisas competentes. Não! O conhecimento é impregnado de intenções, carregado de conflitos, de interesses, de ideologias. Sua produção e/ou reprodução reflete as tendências, interesses, ideologias presentes em cada preríodo da história das "civilizações".

É preciso identificar o conhecimento como algo criado, produzido e reproduzido durante milhares de anos e, como fruto da produção humana é passível de erros, equívocos e acertos. Como fruto da produçaõ humana não são eternos, acabados, definitivos e, portanto, não podem se constituir em verdades absolutas. $O$ 


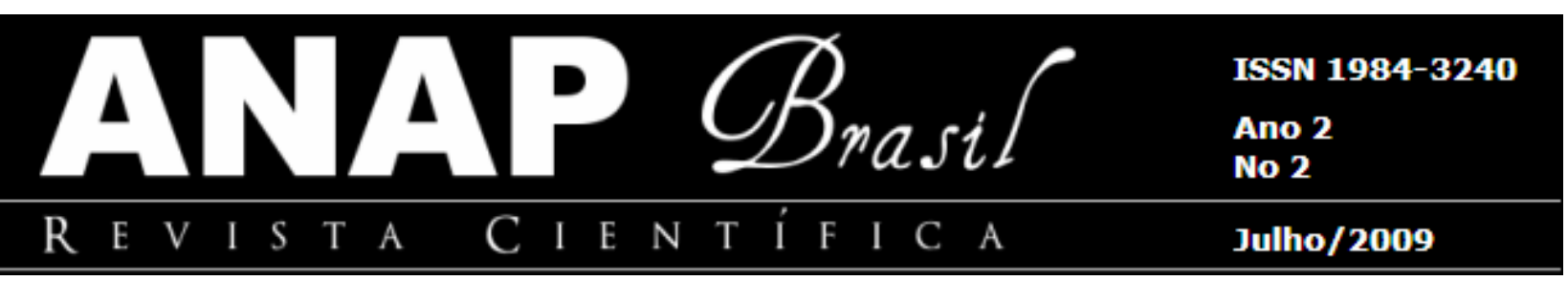

conhecimento é, pois, algo construído segundo as experiências e anseios humanos e, desta forma encharcado de intenções, algumas delas as piores possíveis.

Peter Burke (2003, p.31) afirma que "a maioria dos estudos sobre o conhecimento se ocupa do conhecimento das elites, ao passo que os estudos de cultura popular têm relativamente pouco a dizer sobre seu elemento cognitivo, 0 conhecimento popular ou cotidiano". De fato, o conhecimento considerado válido é aquele que serve para legitimar a lógica do chamado "progresso", arduamente defendido pelas elites, em cada período da história da humanidade. Desta forma, o conhecimento produzido pela maioria das populações é considerado inválido, inútil, descartável, contrário às idéias de progresso consagrada através dos tempos pelos dominantes.

Para se analisar um discurso é preciso perceber a relação todo/partes, não se esquecendo que o ecossistema terrestre é um todo. Morin (2005, p. 37) disserta sobre esta afirmativa:

\begin{abstract}
O global é mais que o contexto, é o conjunto das diversas partes ligadas a ele de modo inter-retroativo ou organizacional. Dessa maneira, uma sociedade é mais que um contexto: é o todo organizador de que fazemos parte. O planeta Terra é mais do que um contexto: é o todo organizador e desorganizador de que fazemos parte. $O$ todo tem qualidades ou propriedades que não são encontradas nas partes, se estas estiverem isoladas umas das outras, e certas qualidades ou propriedades das partes podem ser inibidas pelas restrições do todo. [...] É preciso efetivamente recompor o todo para conhecer as partes.
\end{abstract}

Para tanto, é imprescindível analisar o discurso como um todo, com desconfiança e ao mesmo tempo com frieza e com criticidade. Na maioria das vezes ele se embasa em questões abstratas, subjetivas, próprias do pensamento e do exercício intelectual do ser humano, que age, deliberadamente, de forma disfarçada, camuflada, dissimulada e, até mesmo de forma inescrupulosa e impiedosa. Para se apreender a realidade de um discurso é necessário compreender seus labirintos, que a cada passo podem ocultar uma armadilha. Para se apreender a realidade do discurso é preciso penetrar em suas entrelinhas, perceber as intenções do 


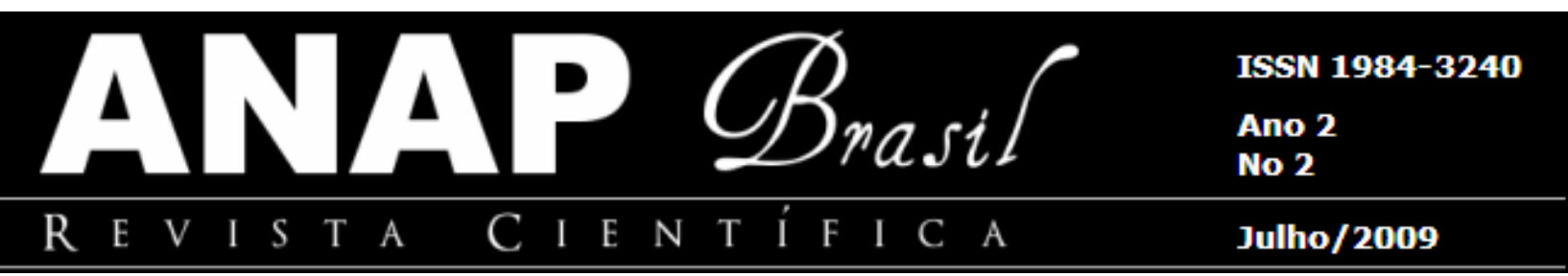

pensamento, do que não está expresso em suas representações, em suas significações. Atrás de uma suposta realidade pode estar oculta uma banalidade, uma falsificação. As representações presentes no discurso são carregadas de intenções, em grande parte obscuras, elas podem ocultar, muitas vezes, inúmeras possibilidades de interpretação, embasadas em argumentações, que apontam várias reflexões, múltiplas análises.

As armadilhas estão presentes na pretensa defesa do "ecologicamente correto" embutido no discurso pseudodesenvolvimentista da produção do etanol. De repente, a prática das monoculturas (em especial a cana-de-açúcar), responsável pelas manchas de sangue, torturas, escravidão e massacres de diversas culturas e etnias (para não falar no prejuízo ambiental), vira a grande heroína, a salvadora da população do país e até da humanidade, diante da crise energética.

\subsection{QUAIS OS CRITÉRIOS PARA A AVALIAÇÃO DOS BIOCOMBUSTÍVEIS COMO "ECOLOGICAMENTE CORRETOS"?}

Esta é uma boa indagação. O grande mote da defesa dos biocombustíveis está, exatamente, na preservação do ambiente, pois, eles [os biocombustíveis] como "energia limpa", lançam menos poluentes para a atmosfera e, conseqüentemente, diminuem a poluição, auxiliando na minimização dos efeitos das alterações climáticas, resultantes do aquecimento global. Ninguém discorda que os biocombustíveis, de fato, lancem menos poluentes para a atmosfera. Mas seus árduos defensores falam como se estes combustíveis existissem "in natura" no planeta.

Não entram no mérito dos processos que compõem sua cadeia produtiva. Partem da idéia de que nesses processos não estão envolvidos os solos, a remoção de vegetação, o uso intensivo de agrotóxicos, o uso de diversos tipos de insumos agrícolas, a queima da palhada (no caso da cana), a precarização das condições de 


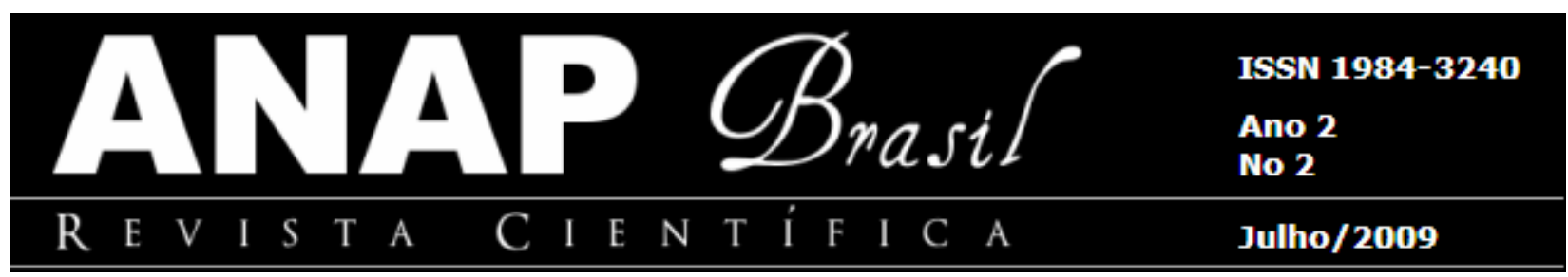

trabalho humano, a concentração de rendas e de terras por parte dos grandes monopólios multi/transnacionais, a contaminação dos corpos d'água, dentre inúmeras outras variáveis, enfim, a degradação ambiental e social. É exatamente sobre estes aspectos que o texto pretende dissertar, a partir do próximo tópico.

\title{
4.2 A PRODUÇÃO DO ETANOL E OS IMPACTOS SÓCIO-AMBIENTAIS SOBRE OS BIOMAS BRASILEIROS
}

Para iniciar esta discussão é importante retomar a história da monocultura canavieira no Brasil e, conseqüentemente na América Latina. É interessante analisar uma formulação de Eduardo Galeano. O escritor Uruguaio explica, com maestria, a origem da política fundiária brasileira, ou melhor, a origem dos latifúndios no Brasil:

\begin{abstract}
As terras foram cedidas pela Coroa portuguesa, em usufruto, aos primeiros grandes senhores de terra do Brasil. A façanha da conquista tinha de correr paralelamente à organização da produção. Somente doze "capitães" receberam, por carta de doação, todo o imenso território colonial virgem, para explorá-lo a serviço do monarca. Todavia, foram capitais holandeses os que financiaram, em maior medida, o negócio, o que foi, em resumo, mais flamengo do que português. As empresas holandesas não só participaram na instalação dos engenhos e na importação dos escravos; além disso, recolhiam o açúcar bruto em Lisboa, refinavam-no, ganhando lucros que chegavam à terça parte do valor do produto, e o vendiam na Europa. Em 1630, a Dutch West India Company invadiu e conquistou a costa nordeste do Brasil, para assumir diretamente o controle do produto. (GALEANO, 2002, p.73-74)
\end{abstract}

Qualquer semelhança com os acontecimentos dos tempos atuais não é mera coincidência. O relato de Galeano mostra exatamente como se deu o início da concentração de terras no Brasil. As benesses e as trocas de favores econômicos e políticos não são nenhuma novidade. Tais "acertos" políticos e econômicos, fatos cotidianos nos tempos atuais, são intrínsecos das origens de nosso processo de 


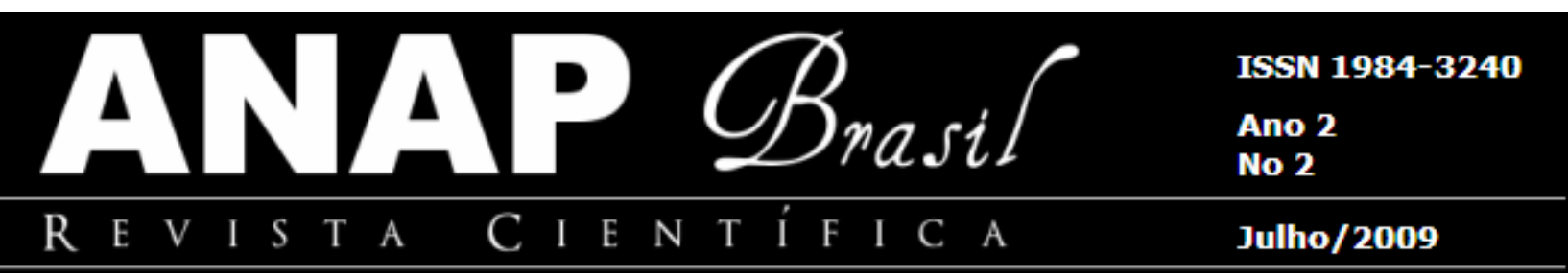

colonização. Os senhores da indústria sucroalcooleira dos dias de hoje não abandonaram os antigos métodos, utilizados por seus antepassados.

A indústria sucroalcooleira necessita de toda uma logística e toda uma infraestrutura para funcionar. Além disso, são necessárias grandes quantidades de adubos, insumos agrícolas para o cultivo da cana-de-açúcar. Com o desenvolvimento da biotecnologia, os grandes grupos multi/transnacionais ligados à indústria de fertilizantes, implementos e equipamentos agrícolas, produção de raízes, detêm o monopólio de todos os insumos necessários à produção e cultivo da cana, o que exclui da cadeia produtiva os pequenos agricultores. O pequeno produtor acaba arrendando suas terras para os usineiros. Aí se inicia o processo de concentração de terras nas mãos dos grandes empresários ligados ao setor e a concentração de capitais nas mãos dos banqueiros, usineiros e montadoras de automóveis.

Os pequenos produtores rurais, não conseguindo acompanhar a tecnologia agroindustrial que invade o campo e/ou não conseguindo arcar com os preços impostos pelos oligopólios de insumos e equipamentos agrícolas, se vêem obrigados a arrendar suas terras (por 10, 20 ou 30 anos) para os usineiros. Estes despejam milhares de toneladas de agrotóxicos e insumos para aumentarem a produção e, ao cabo de, aproximadamente, 30 anos tornam as terras estéreis. Aí, devolvem-nas para os pequenos produtores. Arrendam terras produtivas e devolvem "pedaços de deserto". Toda essa prática tem sido executada, sem nenhum Estudo de Impactos Sócio-Ambientais.

\subsubsection{Impactos sobre o solo}

É notória, na prática das monoculturas, a utilização intensiva de insumos agrícolas e agrotóxicos, em especial nos solos do Cerrado, marcados pela elevada acidez. Outro fator que chama à atenção é a remoção da vegetação e a homogeneização de culturas, o que contribui para a destruição de espécies 


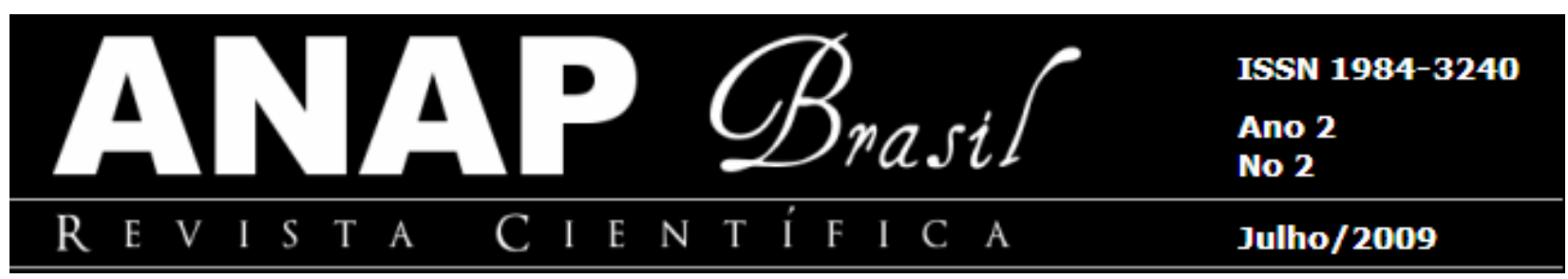

endêmicas e a diminuição dos microorganismos presentes no solo, fundamentais para a aeração do solo e pela manutenção da micro-fauna, que auxilia, sobremaneira, na preservação da qualidade e na fertilidade destes solos.

Acerca deste aspecto, o Banco de Dados Tropicais (2003, sp.) alerta:

\begin{abstract}
Em geral não se discute a importância dos microorganismos nas questões ligadas à biodiversidade, talvez pela falta de dados referentes ao grupo como um todo. Se considerarmos a biodiversidade total no mundo, teremos que admitir que a vasta maioria da diversidade se aplica aos microorganismos, e não às plantas e animais. O nível de desconhecimento nesse campo é tão grande que cerca de 157.000 novas espécies de microorganismos são descritas anualmente, sendo que aproximadamente metade destes são fungos. A importância dos microorganismos é freqüentemente subestimada. $O$ grupo foi fundamental na evolução e diversificação dos seres vivos e, hoje, tem grande significância na manutenção da vida em todos os níveis: individual, ecossistêmico, e global. $\mathrm{Na}$ manutenção da biodiversidade, os microorganismos têm sua mais importante contribuição em nível de ecossistema, onde proporcionam a base alimentar para todas as cadeias tróficas. Sem microorganismos, a pirâmide trófica não existiria.
\end{abstract}

O BDT ainda informa que diversos "estudos proporcionam uma clara indicação da diversidade de microorganismos do Cerrado". Por exemplo, alguns autores listam "419 espécies fúngicas associadas às cerca de 4.700 espécies de plantas fanerógamas da flora do Distrito Federal". Percebe-se que a prática da monocultura canavieira diminui a diversidade de microorganismos por duas razões básicas: a primeira pela aplicação de fungicidas e outros tipos de agrotóxicos que acarretam a extinção de centenas de espécies presentes na micro-fauna do solo. A segunda se dá pela remoção da vegetação original que estava em associação com estes microorganismos. Ao se remover a vegetação ocorre a morte de centenas de espécies destes organismos.

Outro aspecto fundamental que deve ser destacado é que o sistema radicular da cana-de-açúcar é muito eficiente, no que se refere à extração de água do solo. Ele consegue extrair quase toda a água existente nos micro-poros do solo (água 


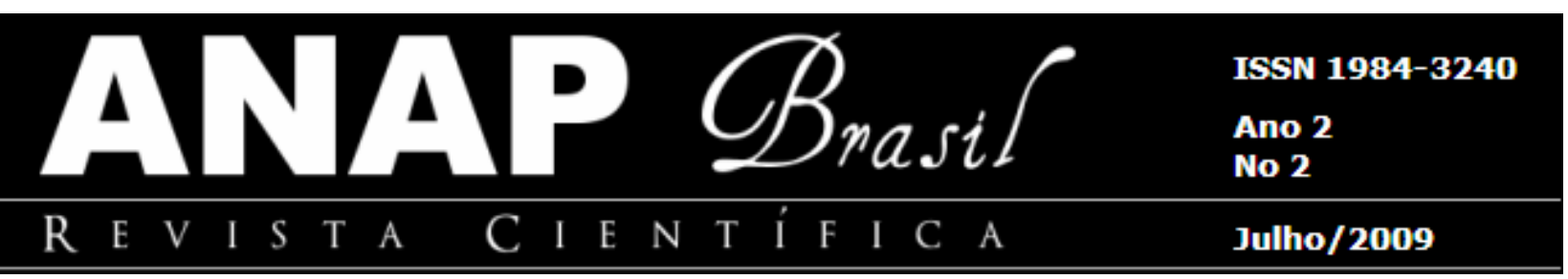

capilar), ressecando-o, deixando-o em vias de desertificação. Assim, a monocultura canavieira produz efeitos altamente desastrosos para os solos.

Ainda é importante ressaltar que a remoção da vegetação e o tráfego de veículos (tratores e equipamentos pesados) utilizados nas plantações causam compactação do solo, além de deixá-lo totalmente exposto aos processos erosivos, provocando o surgimento de ravinas e voçorocas.

4.2.2 Impactos sobre a atmosfera e os corpos d'água (superficiais e subterrâneas)

Grande parte da colheita da cana-de-açúcar se faz com utilização da queima da palhada. Embora exista o discurso da mecanização da colheita, uma boa parcela do plantio é feita em terrenos acidentados, o que impede esta mecanização. A queima da palha da cana lança na atmosfera gases poluentes, em especial o $\mathrm{CO}_{2}$.

Esses gases auxiliam no agravamento da poluição atmosférica, causando diversas doenças respiratórias (estudos comprovam inclusive o aumento do câncer nas regiões de plantações de cana-de-açúcar). Além das doenças, essas queimadas também interferem nas condições climáticas regionais, ocasionando o aparecimento de "ilhas de calor".

A utilização de grandes quantidades de insumos e agrotóxicos, além de contaminar os solos, também contamina os corpos d'água tanto superficiais (pelo carreamento desses produtos pelas chuvas, levando-os diretamente para córregos, riachos ribeirões e rios), quanto subterrâneas (pela infiltração desses poluentes contaminando o lençol freático).

Estudos da UNICAMP apontam o alto grau de contaminação do Aqüífero Guarani (maior reservatório de águas subterrâneas da América do Sul), nas proximidades do município de Ribeirão Preto, um dos maiores produtores sucroalcooleiros do Brasil. 


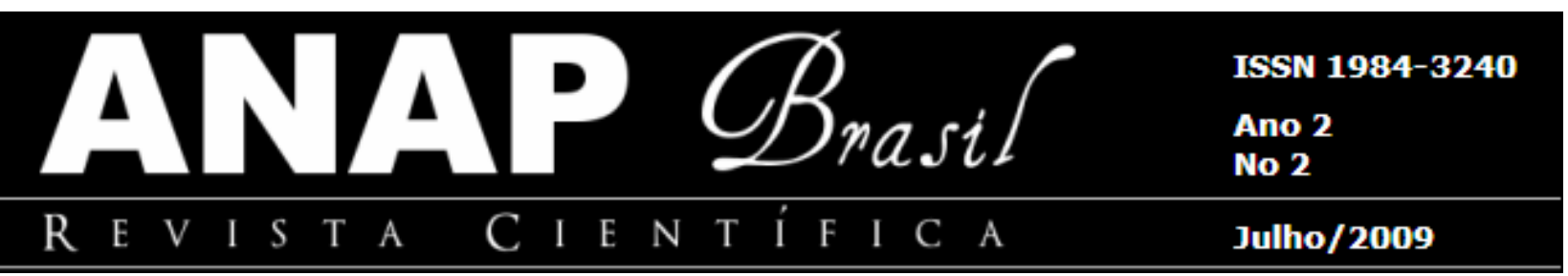

O discurso oficial do Estado brasileiro não leva em consideração esta série de impactos causados aos ecossistemas, em função da monocultura canavieira. A Empresa Brasileira de Pesquisa Agropecuária organizou um esquema dos diversos impactos ambientais sobre os ecossistemas (Figura 1).

\begin{tabular}{|c|c|c|c|}
\hline \multicolumn{4}{|c|}{ IMPACTOS NA ATMOSFERA } \\
\hline $\begin{array}{l}1 \\
\text { Fases do Cultivo }\end{array}$ & Plantio ou Rebrota & Crescimento & Colheita \\
\hline $\begin{array}{l}2 \\
\text { Principais } \\
\text { Operações }\end{array}$ & $\begin{array}{l}\text { Preparo do Solo e/ou } \\
\text { Reforma de Plantio }\end{array}$ & Tratos Culturais & $\begin{array}{l}\text { Colheita Manual ou } \\
\text { Colheita Mecânica }\end{array}$ \\
\hline $\begin{array}{l}3 \\
\text { Técnicas e } \\
\text { Tecnologias }\end{array}$ & $\begin{array}{l}\text { Corretivos } \\
\text { Fertilizantes } \\
\text { Vinhoto } \\
\text { Restos Culturais }\end{array}$ & $\begin{array}{l}\text { Controle Biológico } \\
\text { Inseticidas } \\
\text { Herbicidas }\end{array}$ & $\begin{array}{l}\text { Cana Queimada ou } \\
\text { Cana Crua }\end{array}$ \\
\hline \multicolumn{4}{|c|}{ IMPACTOS NOS SOLOS E NOS AQUÍFEROS } \\
\hline
\end{tabular}

Figura 1: Representação esquemática das várias formas de impactos ambientais da cana. Fonte: EMBRAPA (2006)

A figura 1 mostra os diversos aspectos discutidos nos tópicos anteriores. Pela figura dá para se perceber que, na verdade, esses impactos formam uma cadeia onde os vários aspectos estão interligados e ao mesmo tempo estão presentes em todas as fases (do plantio à colheita).

A EMBRAPA (2006, sp.) afirma que: "Algumas das interações existentes nesse subsistema" (Figura 1), como a poluição atmosférica, por exemplo, "estão sendo 


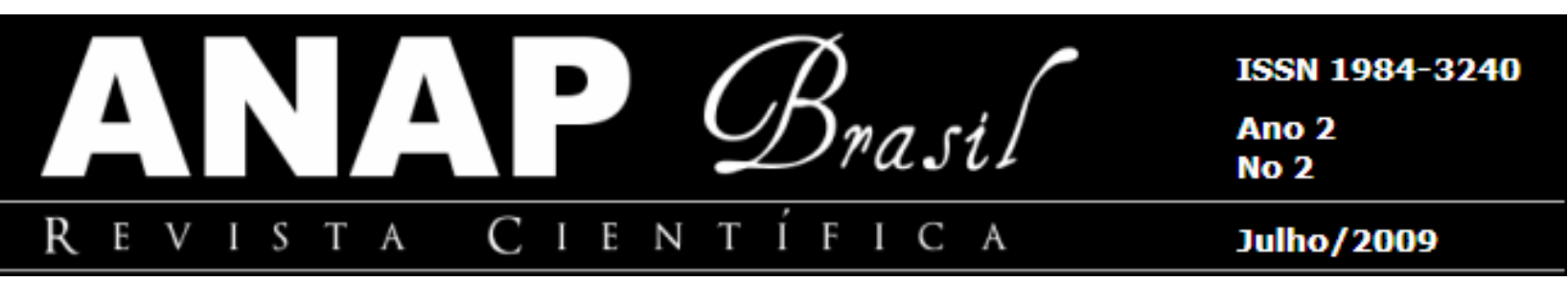

estudadas parcialmente ou monitoradas por instituições, nacionais (INPE, CETESB, Embrapa Monitoramento por Satélite, USP, ECOFORÇA, UNICAMP, CTC etc.) e estrangeiras (EPA)". Ainda segundo a EMBRAPA (2006, sp.):

Com exceção de alguns estudos da Embrapa Monitoramento por Satélite, são poucos os trabalhos de pesquisa que tenham realizado de forma circunstanciada e abrangente a avaliação do impacto ambiental (AIA) da localização atual do cultivo da cana-de-açúcar. Desconhece-se a existência no Brasil de outros trabalhos de avaliação do impacto ambiental da evolução espaço-temporal do uso das terras em regiões canavieiras, cobrindo - por exemplo - a evolução dos últimos 30 anos.

\subsection{OS IMPACTOS SOCIAIS}

Os tempos modernos são marcados, fundamentalmente, pela superexploração da força de trabalho em função da expansão e reprodução do capital. As novas tecnologias aplicadas no campo e na indústria exigem também 0 aumento exponencial da mais-valia para atenuar a crise do modo de produção capitalista na modernidade. Com isso, aparece o trabalho precarizado, terceirizado, aumentando, dessa forma, a degradação das condições de trabalho humanas.

A obra de Marx mantém toda sua atualidade e define a situação pela qual passa a classe trabalhadora na modernidade:

\footnotetext{
O estranhamento do trabalhador em seu objeto se expressa, pelas leis nacional-econômicas, em que quanto mais o trabalhador produz, menos tem para consumir; que quanto mais valores cria, mais sem-valor e indigno ele se torna; quanto mais bem formado seu produto, tanto mais deformado ele fica; quanto mais civilizado seu objeto, mais bárbaro o trabalhador se torna; quanto mais rico de espírito o trabalho, mais pobre de espírito e servo da natureza se torna o trabalhador. (MARX, 2004, p.79 e 85)
}

Assim, as relações de trabalho estão em processo de total deterioração no atual estágio das forças produtivas da sociedade capitalista. No campo estas relações estão ainda mais degradadas, em especial as dos trabalhadores rurais que 


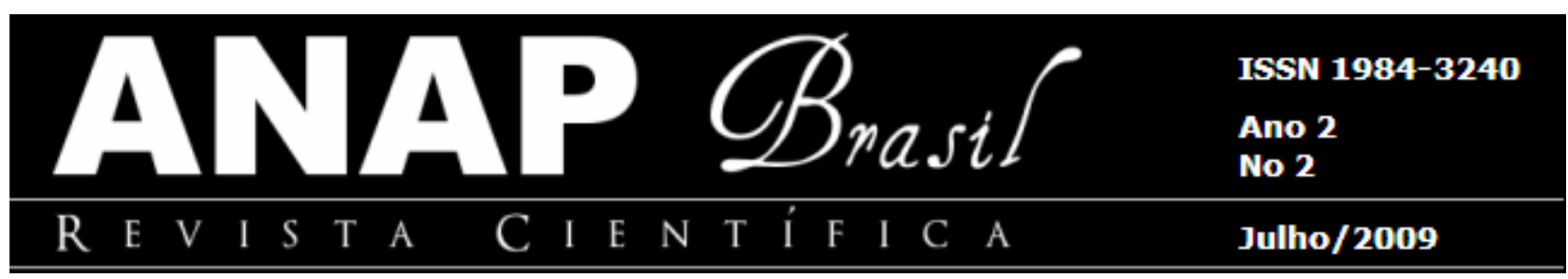

vivem das lavouras de monoculturas. Florestan Fernandes retoma as relações de trabalho na época da escravidão para explicar o processo do sobretrabalho na sociedade capitalista:

[...] O fim da década de 1870 e toda a década de 1880 abrange uma época de agitação apaixonada contra a escravidão, na qual o movimento abolicionista se tornou intrinsecamente revolucionário e se fixaram os parâmetros de que capitalismo e escravidão não podiam coexistir. [...] $O$ modo de produção escravista serviu para construir fortunas das aristocracias da colônia e do Império. Em termos de formação e de expansão do capitalismo como uma realidade histórica interna, ele preencheu as funções de fator de acumulação originária de capital. Quando esse fator se tornou historicamente inoperante e, além disso, passou a ser especificamente capitalista, foi definitivamente condenado ao desaparecimento. [...] Apenas, no Brasil, ele não se deu de maneira completa. [...] ao desaparecer, o trabalho escravo deixou atrás de si várias formas de trabalho semilivre e de trabalho escravo disfarçado que continuam a existir até hoje, mesmo em economias de plantação tidas como "especificamente modernas". (FERNANDES, 2004, p.422-423)

A formulação de Fernandes explica, de forma brilhante o que ocorre, na atualidade nas regiões de monocultura canavieira. A nova geração, descendente da antiga oligarquia rural nordestina exportou seus métodos de deterioração das condições de trabalho humanas para outras regiões do país. Os vestígios de trabalho escravo evidenciado por diversas regiões do Brasil lembram, ainda que de longe, os resquícios do regime feudal. O jornal Folha de São Paulo (FSP) do dia 29 de fevereiro de 2008 traz uma matéria que ilustra bem esta situação:

Em uma megablitz em usinas de cana-de-açúcar em Alagoas, uma forçatarefa do Ministério Público do Trabalho e do grupo móvel do Ministério do Trabalho encontrou mais de 550 trabalhadores em condições degradantes em Rio largo, Marechal Deodoro e Cajueiro. No local, os fiscais dizem ter encontrado trabalhadores sem equipamentos de proteção, vivendo em alojamentos insalubres e sem água potável. Ontem, o corte da cana-deaçúcar foi interrompido pela justiça. [...] "Com certeza, a situação ali nos alojamentos era a pior de todas, insuportável. Os trabalhadores dormiam grudados um no outro, igual a uma cela superlotada", afirmou o subcomandante do grupo, Luiz Carlos Cruz. De acordo com o auditor, a primeira operação no setor sucroalcooleiro no Nordeste mostra que "não há como vender álcool para o exterior com esse tipo de procedimento". "Há descumprimento dos direitos humanos", afirma. (FSP, 29/02/2008, p.A8) 


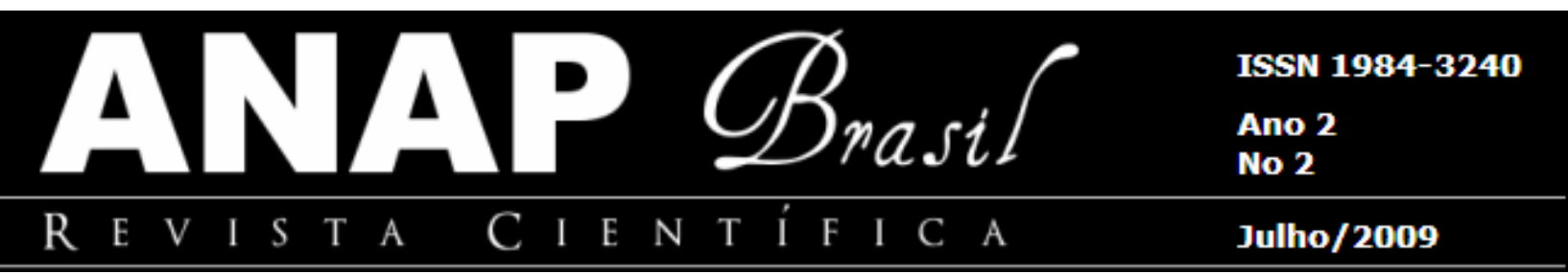

$E$, é nessas condições de pauperização e deterioração das condições de trabalho humano, que as lavouras de cana-de-açúcar se alastram para as diversas regiões do país. Notam-se condições semelhantes em plantações no interior de São Paulo e interior de Minas Gerias, em especial, no Triângulo Mineiro.

Até há pouco tempo atrás (antes da febre da cana), páginas inteiras de jornais, matérias inteiras no rádio e na TV, vinculavam as práticas da monocultura da cana à exploração da mão-de-obra infantil, a torturas e prostituição infantil nos canaviais, a trabalhos escravos e semi-escravos e, até a morte de trabalhadores rurais ligados a esta atividade. Recentemente, a TV exibiu (em horário nobre), uma série de reportagens onde mostrava estes aspectos em várias regiões do país. Destacou entrevistas com usineiros da Região Sudeste, os quais se vangloriavam que os cortadores de cana do Sudeste conseguiam um salário de até $R \$ 800,00$, enquanto no Nordeste ganhavam metade deste valor. Só que eles se "esqueceram" de dizer que para ganhar este salário, cada trabalhador tem que cumprir uma jornada de trabalho de até 12 (doze) horas por dia, cerca de 10 Toneladas de cana cortada/trabalhador/dia, sem direito a descanso semanal. A TV mostrou vários casos de trabalhadores (cortadores de cana) que morreram por fadiga e/ou por estafa objetivando perseguir este "exorbitante" salário.

Estes são alguns aspectos que mostram o grau do impacto social da monocultura canavieira sobre as diversas regiões brasileiras.

\section{PARA NÃO CONCLUIR!!! (CONSIDERAÇÕES PARCIAIS) O DISCURSO DAS CONTRADIÇÕES E AS CONTRADIÇÕES DO DISCURSO!!!}

O mundo contempla, hoje, uma alta considerável nos preços dos produtos básicos da alimentação. Diante deste fato, acirra-se o debate acerca da produção de alimentos $\mathrm{X}$ produção de biocombustíveis. De um lado, assiste-se ao discurso das Nações Unidas atacando os biocombustíveis, de outro lado, o comandante maior do 


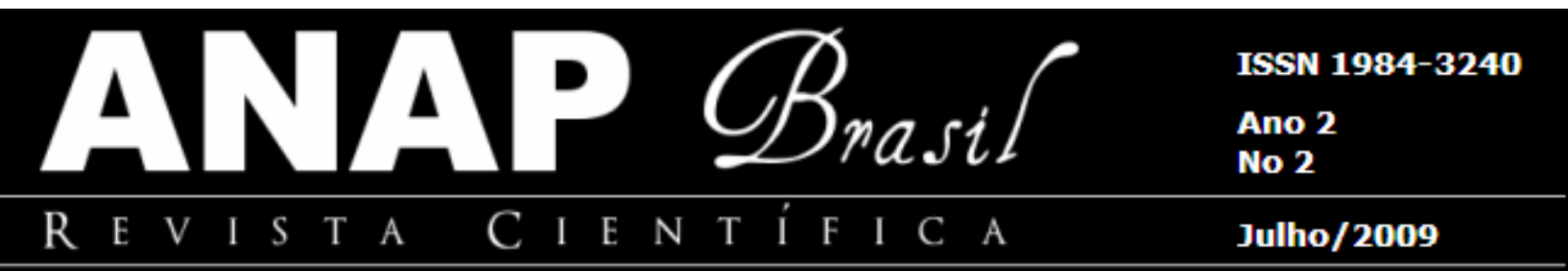

Estado brasileiro, o presidente Luis Inácio Lula da Silva defender com unhas e dentes, o seu marketing político, embutido no "Projeto Etanol". É notória a existência de interesses políticos e econômicos dos dois lados. Porém, um fato fica cada dia mais evidente: cada vez mais aumenta o abismo existente entre a concentração da riqueza no hemisfério Norte e da pobreza no hemisfério Sul. O número de famintos e miseráveis aumenta, de forma considerável em todo o planeta. Este é um problema concreto que precisa ser resolvido com urgência.

Da parte do Brasil, o governo tenta resolver problemas estruturais (como a fome, a subnutrição e a miséria), por intermédio de medidas paliativas. O discurso oficial do Estado brasileiro está imerso num mar de contradições. Tentam justificar a produção dos biocombustíveis por meio de afirmações como "O Brasil tem uma enorme quantidade de terras".

Ora, todos sabem que, felizmente, o Brasil possui um extenso território coberto por solos férteis. Porém, como o próprio texto destaca não se pode justificar a produção da agroenergia sem considerar os diversos tipos de impactos, tanto ambientais quanto sociais, presentes em cada etapa de sua cadeia produtiva. É insano imaginar que os biocombustíveis podem superar a crise energética que permeia a sociedade capitalista dos tempos modernos. É igualmente insano imaginar que eles [os biocombustíveis] podem substituir a matriz energética construída com base na utilização dos combustíveis fósseis.

Por outro lado, o presidente Luis Inácio Lula da Silva, no afã da defesa incondicional dos biocombustíveis, disse em rede nacional que "o governo brasileiro dará todas as condições para que as nações africanas possam produzir biocombustíveis". Ora, o continente africano, ao lado de países como a Índia e de outros das Américas do Sul e Central, são alguns dos locais mais atingidos pela fome, epidemias, subnutrição, AIDS, enfim pela mais absoluta miséria. Como produzir biocombustíveis em países cujas populações não têm, sequer, o que comer? Declarações como esta põe a nu, o que está nas entrelinhas do discurso dos biocombustíveis. 


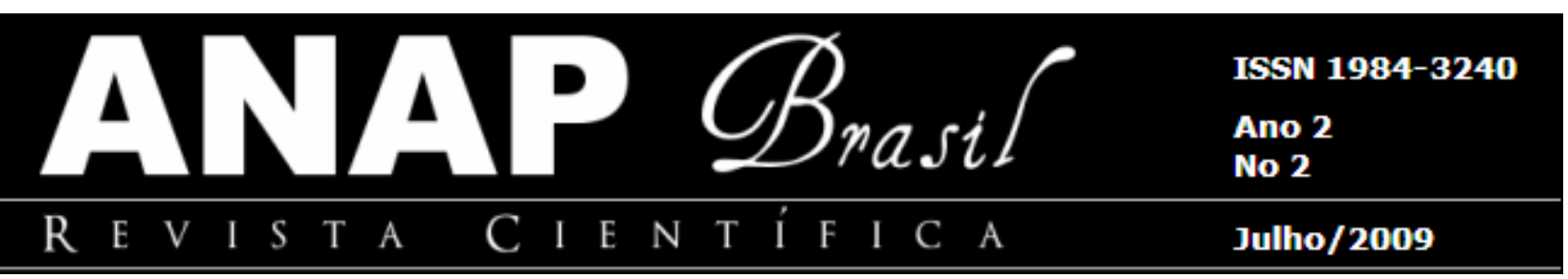

Quanto à produção de novas formas de energia deve-se instigar 0 aperfeiçoamento de novos olhares sobre a problemática. É preciso construir um olhar crítico sobre a temática, com base nos conhecimentos científicos produzidos, procurando acolher os acertos e descartar os erros, aprendendo com eles. A natureza, sabiamente, nos aponta a forma de energia verdadeiramente limpa, a energia solar. Esta energia mantém em atividade as engrenagens mais eficientes, as quais garantem o funcionamento do engenho mais perfeito que se tem conhecimento, a vida, o equilíbrio e a dinâmica da Terra, em sintonia com a dinâmica do universo.

Muitas descobertas do século XX e XXI, como a fissão nuclear, as explosões das bombas de nêutrons e de hidrogênio, são fenômenos que ocorrem naturalmente (milhões de vezes por segundo) na superfície solar. Isso mostra que esta é a fonte de energia mais eficiente e disponibilizada, gratuitamente, pela natureza. Com o advento da nanotecnologia, deve-se investir de forma coerente e séria em pesquisas buscando aprimorar técnicas de captação, transporte e armazenamento de energia solar. Esta, com certeza, é a forma de energia mais eficaz e mais limpa que a natureza já disponibilizou para a humanidade. Dominar os processos de utilização desta forma de energia constitui-se no grande desafio para a ciência, neste limiar do século XXI.

\section{REFERÊNCIAS}

BANCO DE DADOS TROPICAIS - BDT. De grão em grão o cerrado perde espaço: cerrado: impactos do processo de ocupação. Disponível em: http://www.bdt.org.br. Acesso em 2 set. 2003.

FOLHA DE SÃO PAULO. Blitz em Alagoas liberta mais 550 trabalhadores de usinas. In: Folha de São Paulo (FSP), 29 de fevereiro de 2008, p.A8.

BOURNE JR., Joel K. O sonho verde. In: NATIONAL GEOGRAPHIC - Brasil. Outubro de 2007, p.56-77 


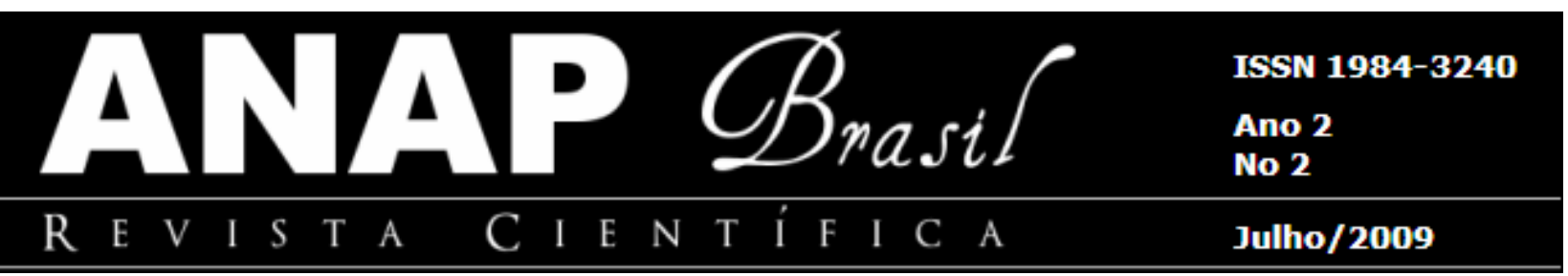

BURKE, Peter. Uma história social do conhecimento. Rio de Janeiro: Jorge Zahar Ed., 2003.

CAMINHA, Pero Vaz de. A carta de Pero Vaz de Caminha. In: Encarte Especial. DESTAQUE IN, ano 5, nำ29, Sacramento (MG), set/out de 1999.

CASTRO, Josué de. Geografia da Fome. (o dilema brasileiro: pão ou aço). 8 ed. São Paulo: Brasiliense: 1963, Vol. 1.

DIAS, Genebaldo Freire. Pegada ecológica e sustentabilidade humana. São Paulo: Gaia, 2002.

EMPRESA BRASILEIRA DE PESQUISA AGROPECUÁRIA - EMBRAPA. Impacto Ambiental da cana-de-açúcar. Disponível em www.cana.cnpm.embrapa.br/ . Acesso em 20 de abril de 2006.

FERNANDES, Florestan. A sociedade escravista no Brasil. In: Florestan Fernandes: sociologia crítica e militante. Octavio lanni (Org.). São Paulo: Expressão Popular, 2004, p.359-424.

GALEANO, Eduardo. As veias abertas da América Latina. 41 ed. Tradução de Galeano de Freitas. Prefácio de Isabel Allende. Rio de Janeiro: Paz e Terra, 2002.

GONÇALVES, Carlos Walter Porto. A globalização da natureza e a natureza da globalização. Rio de Janeiro: Civilização Brasileira, 2006.

HORKHEIMER, Max; ADORNO, Theodor, W. (ORG), Temas Básicos da Sociologia, 2 ed. Trad. Álvaro Cabral, São Paulo: Cultrix, 1986.

MARX, Karl. Manuscritos econômico-filosóficos. São Paulo: Boitempo, 2004.

MORIN, Edgard. Os sete saberes necessários à educação do futuro. Trad.

Catarina Eleonora F. da Silva e Jeanne Sawaya. 10 ed. São Paulo: Cortez; Brasília, DF: UNESCO, 2005. 